\title{
Evaluation of potential in vitro anticancer and antimicrobial activities of synthesized 5-mercapto-4-substituted 1, 2, 4 triazole derivatives
}

\author{
Shailaja P. Desai^, Yasmin H. Momin, Sneha T. Taralekar, Yuvraj D. Dange, Sneha R. Jagtap and Harshad P. Khade \\ Annasaheb Dange College of B. Pharmacy, Ashta-416301, Maharashtra State, India
}

\begin{tabular}{l} 
Article Info \\
\hline Article history \\
Received 19 October 2021 \\
Revised 9 December 2021 \\
Accepted 10 December 2021 \\
Published Online 30 December 2021 \\
\hline Keywords \\
1, 2, 4-triazole \\
Anticancer activity \\
5-Fluorouracil \\
MCF-7 \\
MTT assay
\end{tabular}

\begin{abstract}
A series of 1,2, 4-triazole derivatives $\left(5 \mathrm{a}_{1}-5 \mathrm{a}_{10}\right)$ were synthesized and evaluated for its in vitro anticancer activity. In the present investigation, nicotinic acid refluxed with ethanol to form an ester which further refluxed with hydrazide in alcohol to form an intermediate product carbohydrazide. Finally, this intermediate was condensed and different types of azole derivatives were formed. The synthesized compounds were confirmed through spectral characterization using IR, NMR and MASS. Thereafter, in vitro anticancer activity was performed for synthesized compounds against MCF-7 (Human breast cancer cell line) by MTT assay method using standard 5-Fluorouracil. The labeled compound $5 \mathrm{a}_{1}$ was found to be the most active than others. Thereafter, compounds $5 \mathrm{a}_{2}$, and $5 \mathrm{a}_{5}$ showed appreciable anticancer activity against MCF-7 breast cancer cell line. Furthermore, antimicrobial activity with respect to antibacterial and antifungal activities were performed and showed significant antimicrobial properties with $5 \mathrm{a}_{1}$ and $5 \mathrm{a}_{2}$ when compared with standard ciprofloxacin and fluconazole, respectively. Finally, result concluded that azole derivatives showed potential anticancer and antimicrobial activity synthesized from carbohydrazide.
\end{abstract}

\section{Introduction}

Worldwide, cancer has been a constant battle with a lot of development in cures and preventative therapies. The disease is continually multiplying in human body cells which are uncontrolled and amorphous mass (Ochwang et al., 2014). Its current treatments include chemotherapy, radiotherapy and chemically derived drugs. Not only that, many herbals are also used for the same with their potent antioxidant nature but the onsets of action are very slow (Malik et al., 2020; Thakur et al., 2020). Chemotherapy, for example, can put patients under a lot of stress and wreak havoc on their health. The chemistry of 1,2,4-triazoles and their fused heterocyclic derivatives has received considerable attention from past few years, owing to their synthetic and effective biological importance. A large number of 1,2,4-triazole-containing ring systems, for example, have been incorporated into a variety of therapeutically promising pharmacological candidates, such as anticonvulsant and anticancer agents (Jawad et al., 2016), antibacterial (Bulut et al., 2010), antifungal (Khalil, 2010), anti-inflammatory, antitubercular (Neslihan, 2009; Devi et al., 2018) and analgesic activity (Neslihan, 2010; Hamid et al., 2020) such as fluconazole, intraconazole, voriconazole. Also, there are known drugs containing the 1,2,4- triazole group, e.g., triazolam, alprazolam, etizolam, and furacylin. Furthermore, sulphurcontaining heterocycles are an important class of sulphur compounds that have the potential to be used in real-world applications. Triazoles act by inhibiting ergosterol biosynthesis through inhibition of the 14 alpha-demethylase. The azole antifungal's basic N3 atom forms a bond with the heme iron of the CYP4 $4_{50}$ prosthetic group in the

Corresponding author: Ms. Shailaja P. Desai
Annasaheb Dange College of B. Pharmacy, Ashta-416301, Maharashtra
State, India.
E-mail: shailaja.desaiadcbp@gmail.com
Tel.: +91-7058666757

Copyright (c) 2021 Ukaaz Publications. All rights reserved.

Email: ukaaz@yahoo.com; Website: www.ukaazpublications.com position normally occupied by activated oxygen, and the remaining azole antifungal molecules form bonding connections with the apoprotein, which influences the drug's relative selectivity for the fungal demethylase and other CYP450 enzymes (Guo et al., 2021). Furthermore, potential antibacterial and antifungal activities are also important to evaluate in current days for the significant protection of the foods, beverages and food supplements due to microbial spoilage. Hence, it is also necessary to evaluate the same with the novel derivates of 1, 2, 4-triazole.

Therefore, it was worthwhile to evaluate the synthesized 1,2,4triazole derivatives $\left(5 \mathrm{a}_{1-} 5 \mathrm{a}_{10}\right)$ for its in vitro anticancer, antimicrobial and antifungal activities and revealed the better triazole derivative among the others.

\section{Materials and Methods}

Open capillary methods on a 'Veego' VMP-D apparatus was used for determination of melting point and are corrected. TLC was performed using silica gel $\mathrm{G}$ plates of size $3 \times 8 \mathrm{~cm}$ (Sigma-Aldrich). The IR spectra $(\mathrm{KBr})$ were determined on JASCO FTIR 4100, Mass spectra were recorded on Thermo Fisher Scientific mass spectrometry instruments and $1 \mathrm{H}$ NMR spectra were recorded at $\mathrm{CDCl} 3$ solution. Tetramethylsilane (TMS) was used as an internal standard.

\subsection{Reaction scheme}

The reaction scheme for the synthesis of derivatives from 1,2,4triazole was described below in Figure 1:

Step 1: Synthesis of ethyl pyridine-3-carboxylate (compound 1)

A mixture of nicotinic acid (36 gm, $0.3 \mathrm{~mol})$, absolute ethanol (115 $\mathrm{ml}, 2 \mathrm{~mol})$ and conc. sulphuric acid $(50 \mathrm{ml})$ was refluxed on a steam bath for 3-4 h the solution was cooled to room temperature and poured slowly with stirring onto crushed ice. Sufficient ammonia solution was added to render the resulting solution strongly alkaline 
(up to $\mathrm{pH} 11$ ). The reaction mixture was extracted with seven $50 \mathrm{ml}$ portion of ether and the combined ethereal extracts were dried over magnesium sulphate, solvent was removed by distillation to give yellow colored liquid.

Step 2: Synthesis of pyridine-3-carbohydrazide (compound 2)

A mixture of ethyl pyridine-3-carboxylate (15 gm, 0.1 mole) and hydrazine hydrate (98\%) (5 gm, 0.1 mole) was refluxed for 3-4 h. Then absolute ethanol $(25 \mathrm{ml})$ was added and the reaction mixture was further refluxed for another $h$. The excess of solvent was removed and the residue was poured into ice-cold water $(100 \mathrm{ml})$. The crude solid obtained was recrystallized from ethanol to yield a white crystalline product.

Step 3: Synthesis of substituted potassium salt of dithiocarbazinic acid (compound 3)
Carbon disulphide ( 0.15 mole) was added to a solution of potassium hydroxide $(0.15$ mole), absolute ethanol $(40 \mathrm{ml})$ and pyridine-3carbohydrazide $(0.10$ mole). This mixture was diluted with absolute ethanol $(100 \mathrm{ml})$ and agitated for $18-20 \mathrm{~h}$ and a yellow product was obtained. It was then diluted with dry ether $(250 \mathrm{ml})$ to yield the product, which was collected by filtration

Step 4: Synthesis of 4- amino-5-(pyridine-3yl)-4H-1, 2, 4 triazol3-thiol (compound 4)

A suspension of 3 ( $24 \mathrm{gm}, 0.096$ mole), $98 \%$ hydrazine hydrate (26 $\mathrm{ml}, 0.53 \mathrm{~mole})$ and water $(45 \mathrm{ml})$ was refluxed with stirring for 3-4 h. A white solid was precipitated by dilution with cold water $(100 \mathrm{ml})$ and acidified with concentrated $\mathrm{HCl}$ filtered, washed with cold water and recrystallized from ethanol (Table $1 \mathrm{a}, \mathrm{b})$.

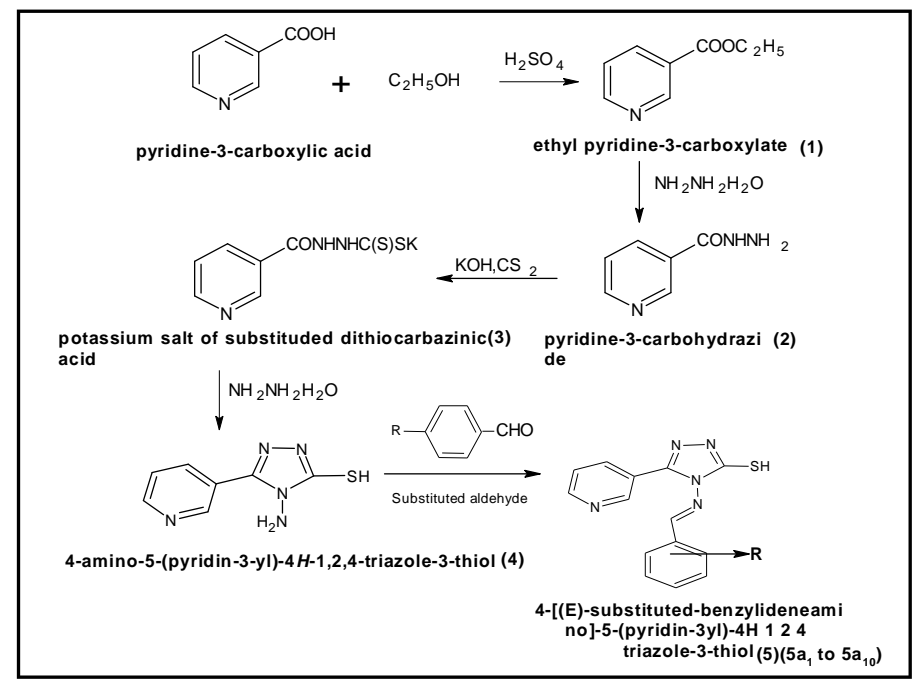

Figure 1: Reaction scheme for the novel derivatives.

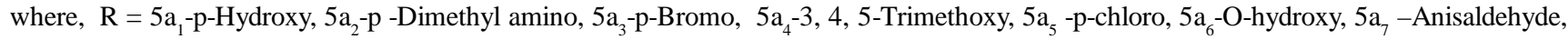
$5 \mathrm{a}_{8}$-p-Nitro, $5 \mathrm{a}_{9}$-p-Fluro, $5 \mathrm{a}_{10}$-m-nitro.

Table 1a: List of synthesized derivatives

\begin{tabular}{|c|c|c|c|c|c|c|c|}
\hline \multirow[t]{2}{*}{ Sr. No. } & \multirow[t]{2}{*}{ Compounds } & \multicolumn{5}{|c|}{ By conventional method } & \multirow[t]{2}{*}{ Mobile phase } \\
\hline & & Molecular formula & MW & $\%$ Yield & $\begin{array}{l}\text { Melting } \\
\text { point }\left({ }^{0} \mathrm{c}\right)\end{array}$ & Rf value & \\
\hline 1 & 1 & $\mathrm{C}_{8} \mathrm{H}_{9} \mathrm{NO}_{2}$ & 153 & 70 & $220-222$ & 0.8 & Ethanol:E.A.,8:1 \\
\hline 2 & 2 & $\mathrm{C}_{6} \mathrm{H}_{7} \mathrm{~N}_{3} \mathrm{O}$ & 136 & 68 & $161-163$ & 0.9 & Ethanol:E.A.,8:1 \\
\hline 3 & 3 & $\mathrm{C}_{7} \mathrm{H}_{6} \mathrm{~N}_{3} \mathrm{~S}_{2} \mathrm{~K}$ & 235 & 53 & $165-167$ & 0.7 & Ethanol:E.A.,8:1 \\
\hline 4 & 4 & $\mathrm{C}_{7} \mathrm{H}_{7} \mathrm{~N}_{5} \mathrm{~S}$ & 193 & 65 & $210-212$ & 0.7 & Ethanol:E.A.,8:1 \\
\hline 5 & $5 a_{1}$ & $\mathrm{C}_{14} \mathrm{H}_{10} \mathrm{~N}_{5} \mathrm{OS}$ & 282 & 61.63 & $260-262$ & 0.79 & Ethanol:E.A.,8:1 \\
\hline 6 & $5 a_{2}$ & $\mathrm{C}_{16} \mathrm{H}_{15} \mathrm{~N}_{6} \mathrm{~S}$ & 309 & 47.51 & $230-232$ & 0.75 & Ethanol:E.A.,8:1 \\
\hline 7 & $5 a_{3}$ & $\mathrm{C}_{14} \mathrm{H}_{9} \mathrm{~N}_{5} \mathrm{SBr}$ & 345 & 70.73 & $180-182$ & 0.83 & Ethanol:E.A.,8:1 \\
\hline 8 & $5 a_{4}$ & $\mathrm{C}_{17} \mathrm{H}_{16} \mathrm{~N}_{5} \mathrm{SO}_{3}$ & 356 & 65.76 & $275-280$ & 0.7 & Ethanol:E.A.,8:1 \\
\hline 9 & $5 a_{5}$ & $\mathrm{C}_{14} \mathrm{H}_{11} \mathrm{~N}_{5} \mathrm{SCl}$ & 307 & 67.89 & $240-245$ & 0.9 & Ethanol:E.A.,8:1 \\
\hline 10 & $5 a_{6}$ & $\mathrm{C}_{14} \mathrm{H}_{9} \mathrm{~N}_{5} \mathrm{SO}_{2}$ & 311 & 72.16 & $240-245$ & 0.86 & Ethanol:E.A.,8:1 \\
\hline 11 & $5 a_{7}$ & $\mathrm{C}_{15} \mathrm{H}_{12} \mathrm{~N}_{5} \mathrm{SO}$ & 310 & 69.70 & $230-235$ & 0,8 & Ethanol:E.A.,8:1 \\
\hline 12 & $5 a_{8}$ & $\mathrm{C}_{14} \mathrm{H}_{9} \mathrm{~N}_{5} \mathrm{SO}_{2}$ & 311 & 55.90 & $210-215$ & 0.5 & Ethanol:E.A.,8:1 \\
\hline 13 & $5 a_{9}$ & $\mathrm{C}_{14} \mathrm{H}_{11} \mathrm{~N}_{4} \mathrm{SCl}$ & 307 & 51.13 & $200-205$ & 0.91 & Ethanol:E.A., $8: 1$ \\
\hline 14 & $5 a_{10}$ & $\mathrm{C}_{14} \mathrm{H}_{9} \mathrm{~N}_{5} \mathrm{SO}_{2}$ & 311 & 51.09 & $240-245$ & 0.67 & Ethanol:E.A.,8:1 \\
\hline
\end{tabular}


Table 1b: Chemical structures of synthesized derivatives

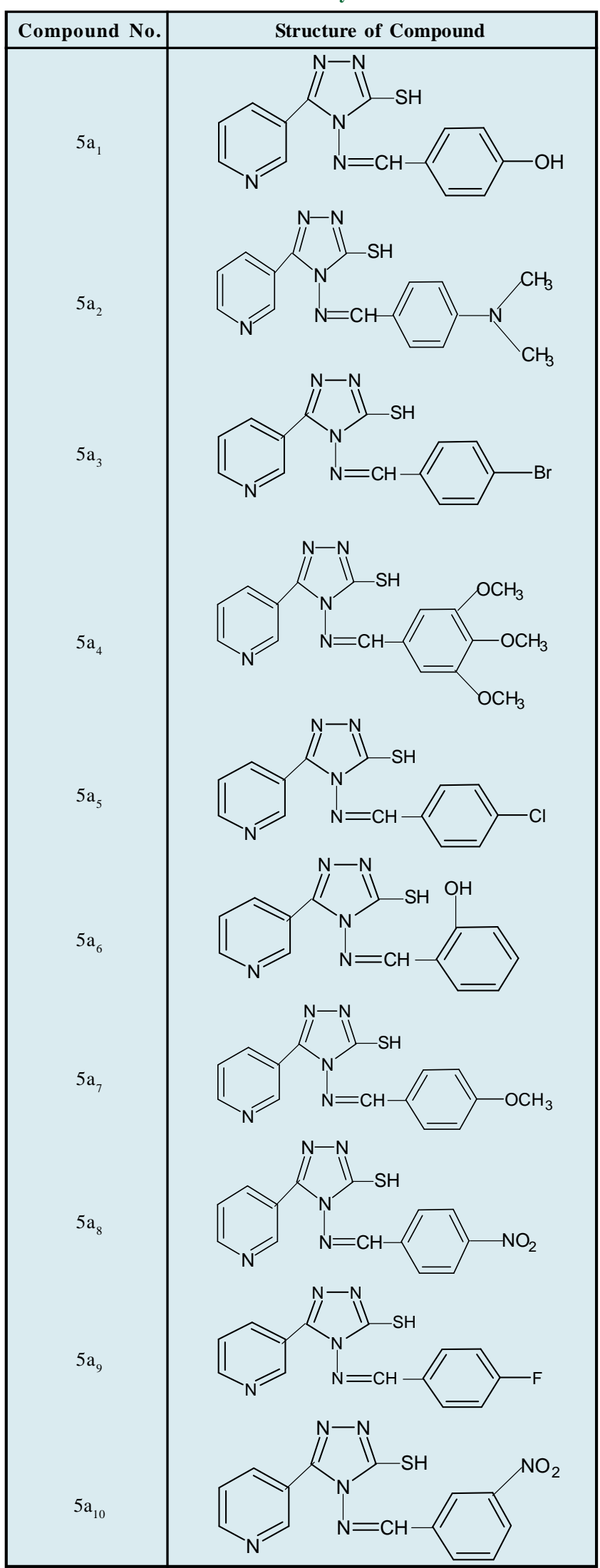

\subsection{Biological evaluation}

\subsubsection{Anticancer evaluation of compound on MCF-7 (Breast cancer cell line) by MTT assay}

Viability assay for the MCF-7cell line was done using 3-(4,5dimethylthiazol-2-yl)-2,5-diphenyltetrazolium bromide (MTT) assay. The MCF7 cell line was maintained in dulbecco $2 \mathrm{~s}$ modified eagle2 s medium (DMEM) with 10\% fetal bovine serum. DMEM is a four-fold concentration of amino acids and vitamins in comparison to Basal Medium Eagle (BME). The cells were plated at a density of $1 \times 10^{4}$ cells per well in a 96-well plate, and cultured for $48 \mathrm{~h}$ at $37^{\circ} \mathrm{C}$. The cells were subsequently exposed to $01 \mathrm{mM}$. The plates were incubated for $24 \mathrm{~h}$, and cell proliferation was measured by adding $10 \mu \mathrm{l}$ of MTT (thiazolyl blue tetrazolium bromide) dye ( $5 \mathrm{mg} / \mathrm{ml}$ in phosphate-buffered saline) per well. The plates were incubated for a further $4 \mathrm{~h}$ at $37^{\circ} \mathrm{C}$ in a humidified chamber containing $5 \% \mathrm{CO}_{2}$. Formazan crystals formed due to reduction of dye by viable cells in each well were dissolved in 200 $\mu 1 \mathrm{DMSO}$, and absorbance was read at $490 \mathrm{~nm}$. The results were compared with the standard drug inhibitors 5-flurouracil $(20 \mu \mathrm{g} /$ $\mathrm{ml})$. Finally, the per cent inhibition of the compounds was calculated by using the formula:

$\%$ Inhibition $=\frac{\text { Reading of control }- \text { Reading of treated cells }}{\text { Reading of control }} \times 100$

The $\mathrm{IC}_{50}(\mu \mathrm{g} / \mathrm{ml})$ values for the cell line was determined as the concentration of drug needed to produce $50 \%$ inhibition of cell growth (Gezici, 2018).

\subsubsection{Antimicrobial screening}

\subsubsection{Test organism}

Four bacterial species were considered, two gram-positive bacteria such as Bacillus subtillis, Staphylococcus aureus, and two gramnegative bacteria, Salmonella typhi and Escherichia coli. Clinical isolates of these microorganisms were maintained on nutrient broth at $2^{\circ} \mathrm{C}$. Thereafter, Candida albicans and Aspergillus niger were used for the antifungal activity which were maintained on Sabourauds dextrose agar slants and stored at $4{ }^{\circ} \mathrm{C}$ prior to use.

\subsubsection{In vitro antibacterial activity}

The modified agar well diffusion method was applied with $5 \mathrm{~mm}$ sterile borer and the study was conducted as per the method described in the literature (Wali et al., 2020). About $20 \mathrm{ml}$ of molten Mueller hinton agar was poured into a sterile Petri plate (Himedia, Mumbai, India). The plates were allowed to solidify, after $18 \mathrm{~h}$ (OD adjusted to 0.6) $100 \mu \mathrm{l}$ of above said type strains were transferred onto plate and made culture lawn by using sterile L-rod spreader. The derivatives were dissolved at concentration of 300 $\mu \mathrm{g} / \mathrm{ml}$ in DMSO, and loaded into wells. Standard drug ciprofloxacin $(10 \mathrm{mg} / \mathrm{ml}$ of DMSO) was used as standard. Incubation time for the plates was at $37^{\circ} \mathrm{C}$ for $24 \mathrm{~h}$. The zone of inhibition was measured using antibiotic zone scale (Himedia, Mumbai, India) to find the antibacterial activity.

\subsubsection{In vitro antifungal activity}

In vitro antifungal activity was determined by disc diffusion method (War et al., 2014). All the synthesized derivatives were dissolved in DMSO at concentration of $300 \mu \mathrm{g} / \mathrm{ml}$. Empty sterile disc having a 
diameter of $5 \mathrm{~mm}$ were impregnated with test compounds and incubated for $15 \mathrm{~min}$ for proper diffusion of extract. One sterile loopful colony was taken from the pure culture and were mixed in nutrient broth $(7 \mu \mathrm{l} / \mathrm{ml}$ broth $)$. This broth was inoculated on entire surface of sabourauds agar plate with the culture moistened cotton swab. All the discs were loaded by derivatives with the help of sterile forceps and placed on inoculated surface of agar plate. Finally, the plates were incubated for $24-72 \mathrm{~h}$ at $25-30^{\circ} \mathrm{C}$ and the zone of inhibition was measured for the antifungal activity. Fluconazole (10 $\mathrm{mg} / \mathrm{ml}$ of DMSO) was used as standard. Triplicate readings were measured by calculating the mean diameter of the inhibition zone (measured in $\mathrm{mm}$ ).

\subsubsection{Statistical analysis}

Results were calculated from triplicate data and expressed as Means \pm standard deviation. The data was analyzed using one-way ANOVA followed by Dunnett comparison test against standard, values with $p<0.01$ was considered significant.

\section{Results}

\subsection{IR, NMR and MASS analysis}

The synthesis of substituted 1, 2, 4 triazole derivatives was carried out by using 5 steps. Total 10 derivatives were prepared traditionally. IR spectra of synthesized compounds were recorded using JASCO FTIR 4100. The H1- NMR Spectra of all synthesized compounds were obtained in $\mathrm{CDCl} 3$ solution with TMS as an internal standard. Further, MASS spectra were recorded for all the samples and finally, the interpretation was made illustrative by the prominent fragmented ion peaks according to their $\mathrm{m} / \mathrm{z}$ values.

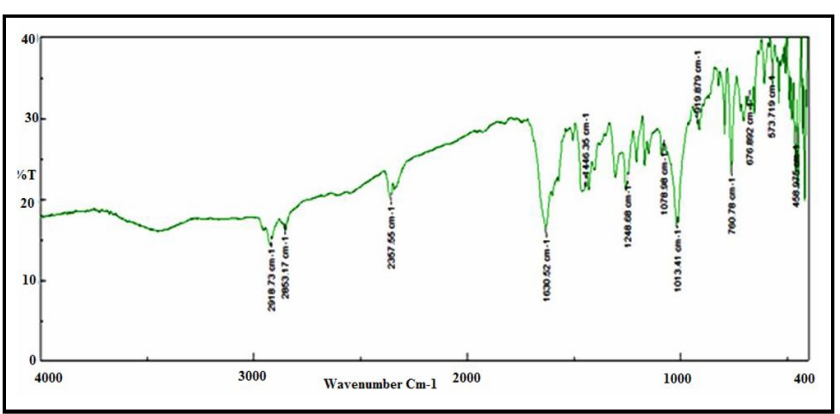

Figure 2a: IR spectra for compound $5 a_{1}$.

Figure 2a showed the position of functional groups in the following ranges: C-C stretching at $1600-1400 \mathrm{~cm}^{-1}, \mathrm{~S}-\mathrm{H}$ bond at $2700-2900$ $\mathrm{cm}^{-1}$, O-H stretching at $3000-3700 \mathrm{~cm}^{-1}$ and C-N-C bond at $1300-$ $1130 \mathrm{~cm}^{-1}$.

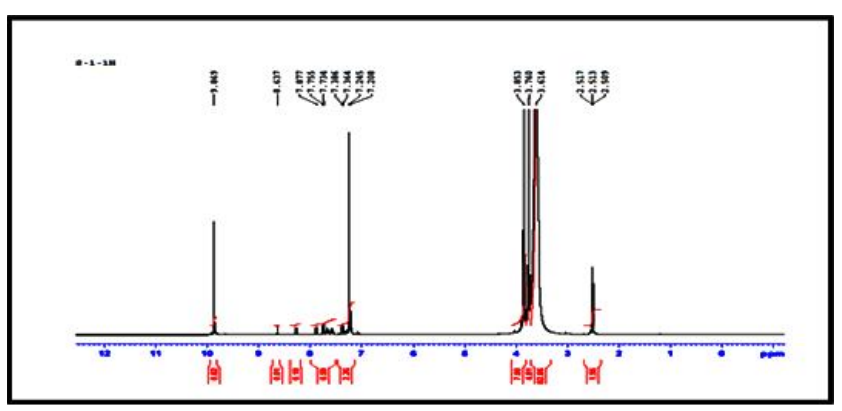

Figure 2b: NMR data for compound $5 a_{1}$.
The NMR data from Figure $2 b$ showed the following chemical shifts tabulated in Table 2 .

The structural elucidation of the synthesized compounds was done by the interpretation of the IR, NMR and MASS Spectra's. All the compounds show satisfactory results of IR, H1-NMR, and MASS spectra. Sample $5 \mathrm{a}_{1}$ was shown in the Figures $2 \mathrm{a}, \mathrm{b}$, c.

Table 2: NMR value of compound $5 \mathrm{a}_{1}$

\begin{tabular}{|c|l|l|}
\hline Sr. No. & Chemical shift & Assignment \\
\hline 1 & $7.8-8.6$ & Aromatic $\mathrm{CH}$ \\
2 & $3.6-3.8$ & $\mathrm{SH}$ \\
3 & 8.6 & $\mathrm{CH}$ \\
4 & 9.8 & $\mathrm{H}-\mathrm{N}$ \\
5 & $7.2-7.8$ & Ar-H, Pyridine ring \\
\hline
\end{tabular}

The MASS spectrum for the same compound was showed in below Figure 2c.

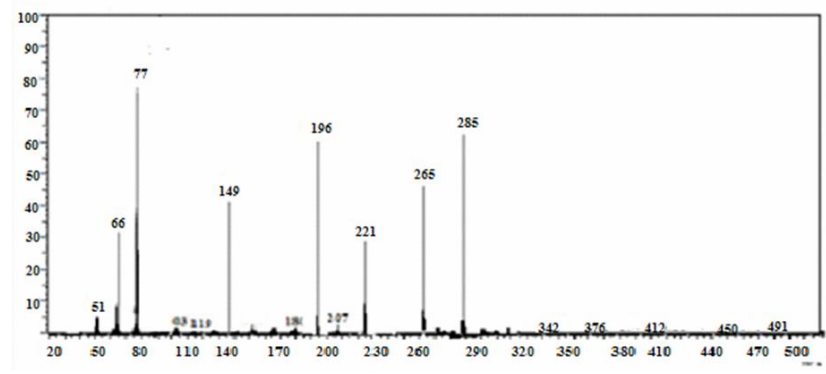

Figure 2c: Mass spectrum of compound 5a1

From the MASS spectra, it showed that the MW value for compound $5 a_{1}$ was 285 whereas the actual value was 282 (Table 3 ).

Table 3: MASS interpretation for compound $5 a_{1}$

\begin{tabular}{|c|c|c|c|}
\hline Sr. no. & $\begin{array}{c}\text { Structure of } \\
\text { compound }\end{array}$ & $\begin{array}{c}\text { Observed } \\
\text { MW }\end{array}$ & $\begin{array}{c}\text { Actual } \\
\text { MW }\end{array}$ \\
\hline 1 & $\begin{array}{c}\text { M-[(4-hydroybenzy } \\
\text { lidene)amino]-5- } \\
\text { (pyridine-3-yl)-4H-1,2, } \\
\text { 4 triazole-3-thiol }\end{array}$ & 285 & $282(\mathrm{~m}-3)$ \\
\hline
\end{tabular}

3.2 In vitro anticancer activity

Anticancer activities of synthesized compounds were screened against MCF-7 (Human breast cancer cell line) by MTT assay method using standard 5-Fluorouracil. Result revealed that significant percentage inhibition by all the synthesized compounds which were more than the positive control, standard 5-fluorouracil $(80.85 \%)$. Compounds $5 \mathrm{a}_{1}$ showed highest inhibition with $92 \%$, followed by $5 \mathrm{a}_{2}(84.01 \%)$ and $5 \mathrm{a}_{5}(83.08 \%)$. The least inhibition showed by compound $5 \mathrm{a}_{9}$ with $43.12 \%$ (Figure 3 ). 


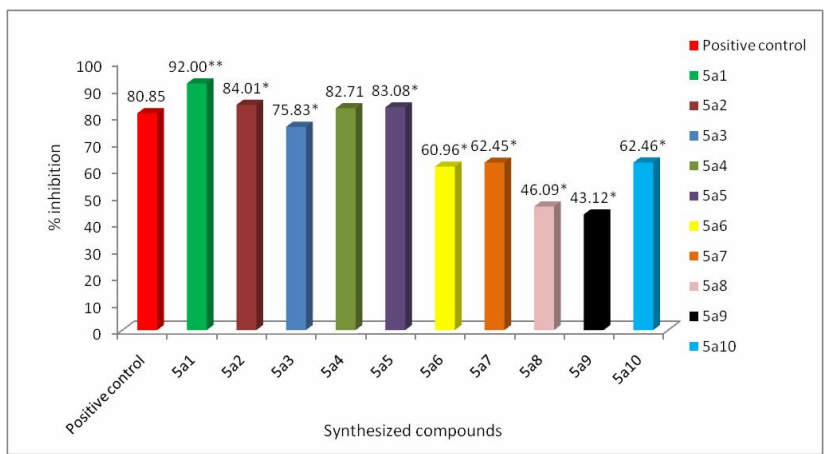

Figure 3: Anticancer activity of synthetic compound $5 a_{1}-5 a_{10}$ against MCF-7 cell line.

Data were analyzed by one-way ANOVA, followed by Dunnett comparison test where samples were compared against standard 5 -fluorouracil. Values were considered significant at $* * p<0.01 ; *$ $p<0.05$.

Furthermore, $\mathrm{IC}_{50}$ values were calculated for all the derivatives and revealed the minimum $\mathrm{IC}_{50}$ value was with $5 \mathrm{a}_{1}(13.47 \pm 1.36)$ which were even lesser than 5-fluorouracil (26.01). The same were resulted for $5 \mathrm{a}_{2}$ and $5 \mathrm{a}_{5}$ were $26.41 \pm 1.03$ and $27.03 \pm 1.24$, respectively (Figure 4).

\subsection{Antibacterial activity}

All the compounds further studied for antibacterial activity against two gram-positive and two gram-negative bacteria and showed potent antibacterial activity by all compounds which were further compared with the standard ciprofloxacin by determined zone of inhibition. Result revealed that compound $5 \mathrm{a}_{1}$ and $5 \mathrm{a}_{2}$ showed higher activities than others and even better activity than the standard (Table 4).

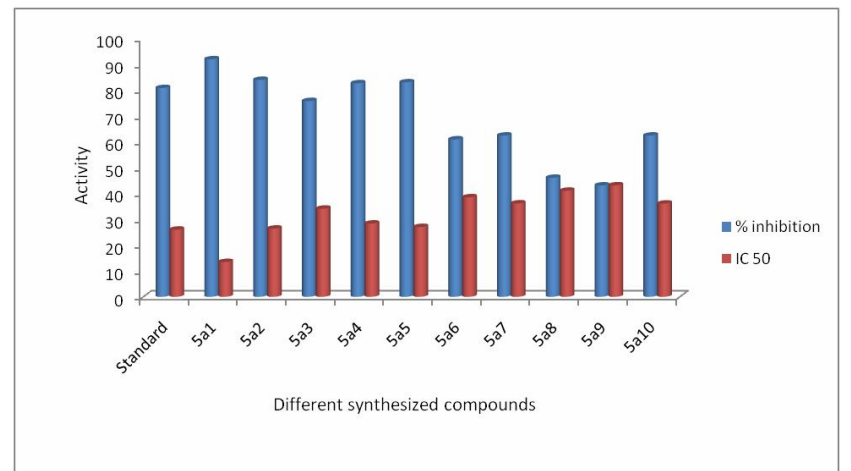

Figure 4:Correlation of $\mathrm{IC}_{50}$ value and \% inhibition for synthesized compound.

Table 4: Antibacterial screening results of synthesized compounds

\begin{tabular}{|c|c|c|c|c|c|}
\hline \multirow{2}{*}{ Sr. No. } & \multirow{2}{*}{ Compound } & \multicolumn{3}{|c|}{ Name of organism (Zone of inhibition in mm) } \\
\cline { 2 - 6 } & & E.coli & S.Typhi & B. Subtilis & S.aureus \\
\hline 1 & $5 \mathrm{a}_{1}$ & $9.8 \pm 1.02$ & $10.7 \pm 1.00^{*}$ & $10.7 \pm 1.02^{*}$ & $13.3 \pm 1.41^{* *}$ \\
2 & $5 \mathrm{a}_{2}$ & $9.6 \pm 1.23$ & $9.8 \pm 1.10$ & $9.8 \pm 1.33$ & $9.9 \pm 1.02^{*}$ \\
3 & $5 \mathrm{a}_{3}$ & $9.6 \pm 1.01$ & $7.2 \pm 1.20$ & $8.2 \pm 1.00$ & $5.7 \pm 0.22$ \\
4 & $5 \mathrm{a}_{4}$ & $8.8 \pm 1.24$ & $5.8 \pm 1.33$ & $7.9 \pm 2.21$ & $6.2 \pm 0.14$ \\
5 & $5 \mathrm{a}_{5}$ & $8.3 \pm 2.10$ & $9.7 \pm 2.40$ & $6.4 \pm 1.34$ & $9.4 \pm 2.33$ \\
6 & $5 \mathrm{a}_{6}$ & $5.7 \pm 1.23$ & $7.2 \pm 1.32$ & $8.2 \pm 0.37$ & $6.7 \pm 1.32$ \\
7 & $5 \mathrm{a}_{7}$ & $7.6 \pm 1.24$ & $6.1 \pm 1.11$ & $5.5 \pm 1.34$ & $5.9 \pm 1.05$ \\
8 & $5 \mathrm{a}_{8}$ & $9.6 \pm 1.22$ & $8.6 \pm 1.22$ & $7.7 \pm 1.22$ & $8.3 \pm 1.51$ \\
9 & $5 \mathrm{a}_{9}$ & $7.2 \pm 1.24$ & $8.9 \pm 0.23$ & $5.5 \pm 1.02$ & $6.6 \pm 1.33$ \\
10 & $5 \mathrm{a}_{10}$ & $5.6 \pm 2.01$ & $5.3 \pm 2.32$ & $5.4 \pm 1.61$ & $5.4 \pm 1.36$ \\
Control & DMSO & - & - & & - \\
Standard & Ciprofloxacin & $8.3 \pm 1.01$ & $6.4 \pm 1.08$ & $8.8 \pm 0.33$ & $8.0 \pm 2.11$ \\
\hline
\end{tabular}

Mean \pm SD $(n=3)$; Data were analyzed by one-way ANOVA, followed by Dunnett comparison test where samples were compared against standard. Values were considered significant at $* * p<0.01 ; * p<0.05$.

\subsection{Antifungal activity}

Furthermore, all the samples were performed for antifungal activity against standard fluconazole and result revealed $5 \mathrm{a}_{1}, 5 \mathrm{a}_{3}, 5 \mathrm{a}_{4}$, and $5 \mathrm{a}_{8}$ compounds showed higher activity against Candida albicans.
Even the values were higher as compared to standard also. In other hand, all the compounds showed less activity than former, but the result showed compound $5 \mathrm{a}_{1}$ gave comparatively higher activity than all other compounds against Aspergillus niger $(9.9 \mathrm{~mm})$. The value was also higher than standard $(8.5 \mathrm{~mm})$ (Table 5$)$. 
Table 5: Antifungal screening of synthesized compounds

\begin{tabular}{|c|c|c|c|}
\hline \multirow{2}{*}{ Sr. No. } & Compounds & \multicolumn{2}{|c|}{ Name of organism (Zone of inhibition in mm) } \\
\cline { 2 - 4 } & & $\begin{array}{c}\text { (Gram-positive fungi) } \\
\text { Candida albicans }\end{array}$ & $\begin{array}{c}\text { (Gram-negative fungi) } \\
\text { Aspergillus niger }\end{array}$ \\
\hline 1 & $5 \mathrm{a}_{1}$ & $10.1 \pm 2.11^{*}$ & $9.9 \pm 2.01^{*}$ \\
2 & $5 \mathrm{a}_{2}$ & $6.1 \pm 1.27$ & $8.9 \pm 2.11$ \\
3 & $5 \mathrm{a}_{3}$ & $9.9 \pm 2.01^{*}$ & $6.7 \pm 1.24$ \\
4 & $5 \mathrm{a}_{4}$ & $9 \pm 1.30$ & $5.3 \pm 2.01$ \\
5 & $5 \mathrm{a}_{5}$ & $8.3 \pm 2.23$ & $8.7 \pm 2.33$ \\
6 & $5 \mathrm{a}_{6}$ & $5.7 \pm 0.34$ & $7.1 \pm 1.82$ \\
7 & $5 \mathrm{a}_{7}$ & $6.9 \pm 1.22$ & $5.5 \pm 2.54$ \\
8 & $5 \mathrm{a}_{8}$ & $9.3 \pm 1.72$ & $6.9 \pm 1.45$ \\
9 & $5 \mathrm{a}_{9}$ & $5.3 \pm 2.30$ & $8.6 \pm 1.33$ \\
10 & $5 \mathrm{a}_{10}$ & $5.1 \pm 0.34$ & $5.2 \pm 0.44$ \\
Control & DMSO & & - \\
Standard & Fluconazole & $8.9 \pm 0.31$ & $8.5 \pm 0.01$ \\
\hline
\end{tabular}

Mean \pm SD $(n=3)$; Data were analyzed by one-way ANOVA, followed by Dunnett comparison test where samples were compared against standard. Values were considered significant at $* p<0.05$.

\section{Discussion}

In the present study, total 14 compounds were synthesized among them, compound 5 further showed 10 different novel synthesized compounds which were biologically screened for their anticancer as well as antimicrobial potentiality.

All the synthesized compounds were subjected to IR, NMR and MASS study for the identification and confirmation of the structural characteristics of unknown or predicted compound. IR spectrum of compound depends upon the number of factors in the molecule such as molecular weight of the compounds, force constants, vibrational coupling, resonance, steric interaction, inter and intermolecular hydrogen bonding. Various groups and environment also affect the vibrational frequencies and their bond intensities. The absorption frequency can change due to various vibration classes such as stretching, bending and scissoring. Each functional group or atom has its own identification or marker frequency to absorb in most of the unaffected or unsuited condition. IR spectrum is thus playing a key role for characterization of new compounds, therefore also called as fingerprint technique. Thereafter, NMR spectra of newly synthesized compounds $\left(5 \mathrm{a}_{1}, 5 \mathrm{a}_{5}\right)$ were obtained with TMS as internal standard. The $1 \mathrm{H}-\mathrm{NMR}$ spectra were performed in $\mathrm{CDCl}_{3}$ solution using Bruker $300 \mathrm{MHz}$ and their chemical shifts were reported in ä units. Mass spectrum of few synthesized compound was obtained from QP-2010 Shimadzu GC-Mass Spectrometer. The molecular ions, the fragment ions and the fragment radical ions separated by deflection a variable magnetic field according to their mass and charge, and generate current at the collector in proportion to their relative abundances. All the interpretation was made illustrative by the prominent fragmented ion peaks according to their $\mathrm{m} / \mathrm{z}$ value. The similar studies were carried out by earlier researchers (Lamani et al., 2008; Dubey et al., 2014).
It was reported that the 1,2,3-triazole derivatives showed interesting antitumor activity. Not only that, 1, 2, 3-triazoles with the thiazole ring are quite active against tumor cell lines because the thiazole fragment directly bound to the 1, 2, 3-triazole core (Pokhodylo et al., 2013). In another research, it was revealed that 1, 2 4-triazole derivatives were also resulted potent anticancer activity against HCT cell lines (Farghaly et al., 2015). The same result was also observed in the present investigation where novel derivatives from 1,2,4-triazole compounds showed potential anticancer activity against MCF-7 breast cancer cell line, assayed by in vitro MTT method. In the assay method, it was revealed that some novel synthesized compounds showed more potent anticancer activity than 5-fluorouracil standard. The same result was also reported by the earlier researcher (Guo et al., 2021). In the present investigation, the synthesized all compounds showed breast cancer cell line (MCF7) specific cell death without significant nuclear DNA damage, it might be due to the formation of reactive oxygen species (ROS) without significant nuclear DNA damage (Kumari et al., 2019). The investigation revealed $\mathrm{IC}_{50}$ values were less in case of few compounds which showed maximum percentage of inhibition. It was also reported by the earlier researchers that lesser $\mathrm{IC}_{50}$ values, the greater the activity. It was seen that $\mathrm{IC}_{50}$ values between $10-50 \mu \mathrm{g} / \mathrm{ml}$, indicated strong antioxidant activity, whereas showed moderate when the values between $50-100 \mu \mathrm{g} / \mathrm{ml}$ and the least when the values between $>100 \mu \mathrm{g} / \mathrm{ml}$ (Phongpaichit et al., 2007). The same trend followed in the present study where some compounds showed very less $\mathrm{IC}_{50}$ values with strong anticancer activity.

Potential antibacterial and antifungal activities were performed and resulted the same trend as shown by the few synthesized compounds. It was due to triazole act by inhibiting ergosterol biosynthesis through inhibition of the 14 alpha-demethylase (Vanden Bossche et al., 1987). The basic $\mathrm{N}_{3}$ atom of the azole 
forms a bond with the heme iron of the CYP450 prosthetic group in the position normally occupied by the activated oxygen, the remainder of the azole antifungal forms bonding interactions with the apoprotein in a manner which determines the relative selectivity of the drug for the fungal demethylase and other CYP450 enzymes (Jeffreys et al., 2019). In the present study, both the activities were observed with few compounds which are more potent than the standards. The result was also correlated with the earlier reports (Bharti et al., 2010; Gupta and Jain, 2015).

\section{Conclusion}

The current research work was aimed to synthesize various azole derivatives and investigation on pharmacological screening of those compounds for anticancer activity and antimicrobial activity. The structural characterization of the synthesized compounds was done by the interpretation of IR, 1H NMR, MASS. All the compounds showed satisfactory IR, 1H NMR data and MASS spectra. Among all synthesized compound, the compounds $5 \mathrm{a}_{1}, 5 \mathrm{a}_{2}, 5 \mathrm{a}_{4}, 5 \mathrm{a}_{5}$ were found to possess significant anticancer activity compared with 5flurouracil. Thereafter, compounds $5 \mathrm{a}_{1} 5 \mathrm{a}_{2}, 5 \mathrm{a}_{5}$ were shown significant antibacterial activity and compounds $5 \mathrm{a}_{1}, 5 \mathrm{a}_{3}, 5 \mathrm{a}_{4}$, and $5 \mathrm{a}_{8}$ showed better activity against fungal strains because of the bulky group and moderate electronegativity. These result indicated that substituting nicotinic acid moiety in to the novel 1,2, 4 triazole ring enhance the potency of the 1,2,4 triazole moiety and useful leads for antimicrobial and anticancer drug development.

\section{Conflict of interest}

The authors declare no conflicts of interest relevant to this article.

\section{References}

Bharti, S.K.; Nath, G.; Tilak, R. and Singh, S.K. (2010). Synthesis, antibacterial and antifungal activities of some novel Schiff bases containing 2,4 disubstituted thiazole ring. Eur J. Med. Chem., 45(2):651-660.

Bulut, V.N.; Duran, C.; Gundogdu, A.; Soylak, M.; Yildirim, N. and Tufekci, M. (2010). A triazole derivatives as a new acid-base indicator. Bull. Chem. Soc. Ethiop., 24(3):457-460.

Dubey, R. K.; Singh, A. P. and Patil, S. A. (2014). Synthesis, spectroscopic characterization and DNA cleavage studies of dibutyltin(IV) complexes of bidentate Schiff bases. Inorg. Chim. Acta., 410:3945 .

Farghaly, T.A.E.R.; Abdallah, M.A. and Mahmoud, H.K. (2015). Synthesis of novel 1,2,4-triazoles and triazolo-thiadiazines as anticancer agents. Turk. J. Chem., 39:955-969.

Gezici, S. (2018). Promising anticancer activity of lavender (Lavandula angustifolia Mill.) essential oil through induction of both apoptosis and necrosis. Anna. Phytomed., 7(2):38-45.

Gupta, D. and Jain, D.K. (2015). Synthesis, antifungal and antibacteria activity of novel 1,2,4-triazole derivatives. J. Adv. Pharm. Technol. Res., 6(3):141-146.

Guo, H.Y.; Chen, Z.A.; Shen, Q.K and Quan, Z.S. (2021). Application of triazoles in the structural modification of natural products. Journal of Enzyme Inhibition and Medicinal Chemistry., 36(1):1115-1144.

Jawad, K.; Shneine1, Y. and Alaraji, H. (2016). Chemistry of 1, 2, 4-triazole: A review. International Journal of Science and Research., 5(3): 1411-1423.
Jeffreys, L. N.; Poddar, H.; Golovanova, M.; Levy, C. W.; Girvan, H. M.; McLean, K. J.; Voice, M. W.; Leys, D. and Munro, A. W. (2019). Novel insights into P450 BM3 interactions with FDA-approved antifungal azole drugs. Scientific Reports., 9(1):1577. https://doi.org/10.1038/s41598018-37330-y.

Khalil, S.A. (2010). Efficient synthesis of novel 1,2,4-triazole fused acyclic and 21-28 membered macrocyclic with potent antimicrobial activity. European Journal. Med. Chem., 4(5):5265-5277.

Kumari, P.; Dubey, S.; Venkatachalapathy, S.; Narayana, C.; Gupta, A. and Sagar, R. (2019). Synthesis of new triazole linked carbohybrids with ROSmediated toxicity in breast cancer. New J. Chem., 43:18590-18600.

Lamani, D.S.; Venugopala Reddy, K.R.; Bhojya Naik, H.S.; Savyasachi, A. and Naik, H.R. (2008). Synthesis and DNA binding studies of novel heterocyclic substituted quinoline Schiff bases: a potent antimicrobial agent. Nucleosides, Nucleotides and Nucleic Acids., 27:1197-1210.

Malik, T.; Madan, V. K. and Prakash, R (2020). Herbs that heal: Floristic boon to the natural healthcare system. Ann. Phytomed., 9(2):1-9.

Neslihan, D. (2009). Synthesis of some new 1,2,4-triazoles, their Mannich and Schiff bases and evaluation for their antimicrobial activities. European Journal Med.Chem., 4(4):1057-1066.

Devi, M.; Sharma A.; Navdeep.; Saroea, S.; Kohli, M.; and Bhatt, A.K (2018). In vitro study of antimicrobial activity of Tinospora cordifolia (Thunb.) Miers plant extracts against selected clinical isolates. Ann. Phytomed., 7(2):76-80.

Neslihan, D. (2010). Synthesis and antimicrobial activities of some new 1,2,4-triazoles derivatives. Molecules., 1(5):2427-2438.

Hamid, N. S., Thakur, R.S., Abhimanyu, T.; Pradeep, K. and Sunakshi, G. (2020). Phytochemical extraction and quantification from wild pomegranate flavedo powder, their antioxidant and antimicrobial properties. Ann. Phytomed., 9(1):187-194.

Ochwang, I.D.O.; Kimwele, C.N.; Oduma, J.A.; Gathumbi, P.K.; Mbaria, J.M. and Kiama, S.G. (2014). Medicinal plants used in treatment and management of cancer in Kakamega County Kenya. Journal of Ethnopharmacology., 151:1040-1055.

Phongpaichit, S.; Nikom, J.; Rungjindamai, N.; Sakayaroj, J.; Hutadilok-Towatana, N.; Rukachaisirikul, V. and Kirtikara, K. (2007). Biological activities of extracts from endophytic fungi isolated from Garcinia plants. FEMS Immunol. Med. Microbiol. 51 (3):517-525.

Pokhodylo, N.; Shyyka, O. and Matiychuk, V. (2013). Synthesis of 1,2,3-Triazole derivatives and evaluation of their anticancer activity. Sci. Pharm., 81:663-676.

Thakur, H.N.S.; Sharma, R.; Thakur, A.; Kumar, P. and Gautam, S. (2020). Phytochemical extraction and quantification from wild pomegranate flavedo powder, their antioxidant and antimicrobial properties. Ann. Phytomed., 9(1):187-194.

Vanden Bossche, H.; Willemsens, G. and Marichal, P. (1987). Anti-candida drugs: The biochemical basis for their activity. Crit. Rev. Microbiol., 15(1):57-72.

Wali,A.F.; Hamad, E.A.; Khazandar,A.A.; Al-Azzawi, A.M.; Sarheed, O.A.; Menezes, G.A. and Alam, A. (2019). Antimicrobial and in vitro antioxidant activity of Salvia officinalis L. against various re-emergent multi drug resistance microbial pathogens. Ann. Phytomed., 8(2):115-120.

War, I.R.; Ganie, S.A.; Agnihotri, R.K.; Sharma, B.; Mahajan, S. and Sharma, R. (2014). Antifungal activity of Cassia fistula Linn. Against some pathogenic fungi. International Journal of Phytomedicine., 6(2): $182-187$. 